\title{
Relationship Between Personality and Music Preferences Among University Students
}

\author{
Tai Minnie, Norashikin Mahmud *, Wan Mohd Azam Wan Mohd Yunus, Nor Akmar Nordin \\ School of Human Resource Development and Psychology, Faculty of Social Sciences and Humanities, Universiti Teknologi Malaysia, 81310 UTM Johor \\ Bahru, Johor, Malaysia \\ *Corresponding author: norasikin@utm.my
}

Article history: Received: 28 June 2021 Received in revised form: 11 July 2021 Accepted: 25 July 2021 Published online: 05 August 2021

\begin{abstract}
This study analysed the relationship between Big Five personality traits and music preferences among university students. Big Five Inventory (BFI) and Short Test of Music Preferences (STOMP) was used to assess personality traits and music preferences. Questionnaires were distributed through social media platforms to college and university students aged 19 to 26. A total number of 145 respondents participated in this study. The results showed Agreeableness, Conscientiousness, and Openness were the most prevalent personality traits among respondents and Energetic-Rhythmic (ER) was the most preferred music. The correlation analysis showed that there is a significant correlation between Openness and energetic-rhythmic (ER) music. On the other hand, there was no significant correlation between other traits (Conscientiousness, Extraversion, Agreeableness, and Neuroticism) with music preference dimensions such as Intense-Rebellious (IR) and Energetic-Rhythmic (ER). The inconsistencies in the literature and our findings suggested more studies are needed to understand the influence of personality on music preferences.
\end{abstract}

Keywords: Big Five Personality traits, music preferences, university and college students

\begin{abstract}
Abstrak
Kajian ini menganalisis hubungan antara sifat keperibadian Big Five dan pilihan muzik di kalangan pelajar universiti. Big Five Inventory (BFI) dan Short Test of Music Preferences (STOMP) digunakan untuk menilai sifat keperibadian dan pilihan muzik. Soal selidik diedarkan melalui platform media sosial kepada pelajar kolej dan universiti berusia 19 hingga 26 tahun. Sebanyak 145 responden mengambil bahagian dalam kajian ini. Hasil kajian menunjukkan Ketekunan, Kesadaran, dan Keterbukaan adalah sifat keperibadian yang paling lazim di kalangan responden dan Energetic-Rhythmic (ER) adalah muzik yang paling disukai. Analisis korelasi menunjukkan bahawa terdapat korelasi yang signifikan antara Openness dan muzik energetic-rhythmic (ER) Sebaliknya, tidak ada hubungan yang signifikan antara sifat lain (Conscientiousness, Extraversion, Agreeableness, and Neuroticism) dengan dimensi pilihan muzik seperti Intense-Rebellious (IR) dan Energetic-Rhythmic (ER). Ketidakkonsistenan dalam literatur dan penemuan kami mencadangkan lebih banyak kajian diperlukan untuk memahami pengaruh keperibadian terhadap pilihan muzik.
\end{abstract}

Kata kunci: Personaliti “Big Five”, pilihan muzik, universiti, dan pelajar kolej

(C) 2021 Penerbit UTM Press. All rights reserved

\subsection{INTRODUCTION}

Music listening behavior occupies a significant portion of our everyday lives. It accompanies us as we carry out simple day-to-day activities such as driving, working, and reading. Past studies reported that people listen to music in various settings (Schäfer, 2016). Individuals place great importance on music. This notion is supported by Rentfrow and Gosling (2003) and Bonneville-Roussy, Rentfrow, $\mathrm{Xu}$, and Potter (2013) that people consider music as essential and believe it as important as a hobby, if not more. When it comes to listening to music, there are many songs that people can choose from, and usually, they show a preference for certain types of music over others. This situation increases researchers' interest in understanding the underlying factors that affect people's choice of music. Also, music preference is related to functions of music such as functions of arousal (Pilgrim, Norris, \& Hackathorn, 2017;) and cognitive (Rentfrow \& Gosling, 2003; Schäfer \& Sedlmeier, 2010). Rentfrow \& Gosling, 2003; Schäfer, 2016; Schäfer \& Sedlmeier, 2010), emotion (Schäfer, 2016; Thompson, Geeves, \& Olsen, 2018; Vuoskoski, Thompson, McIlwain, \& Eerola, 2012

Music is a meaningful way to express one's psychological characteristics; therefore, there is a link between individual personality and music preferences. For example, those experiencing higher resting arousal preferred heavy metal music (Gowensmith \& Bloom, 1997). One classic study found that personality traits such as sensation seeking and antisocial behaviour were positively related to highly arousing music, including heavy metal, rock, alternative, rap, and dance (McNamara \& Ballard, 1999). At present, the relationship between 
personality traits and music preferences yielded conflicting results. For instance, Openness and Extraversion have shown good consistency in predicting different music preferences. Openness has consistently predicted preference for intense music (Cleridou \& Furnham, 2014; Ercegovac, Dobrota, \& Kuscevic, 2015; Ferwerda, Tkalcic, \& Schedl, 2017; Fricke \& Herzberg, 2017; Langmeyer, Guglhor-Rudan, \& Tarnai, 2012). Extraversion predicts preference for music that is energetic and rhythmic (Dys, Schellenberg, \& McLean, 2017; Ferwerda et al., 2017; Fricke \& Herzberg, 2017; Herrera, Soares-Quadros, \& Lorenzo, 2018; Langmeyer et al., 2012). However, for Neuroticism, results from several studies found that it is a predictor for intense music (Fricke \& Herzberg, 2017; Greenberg et al., 2016; Herrera et al., 2018), while other studies showed that Neurotic individuals did not prefer intense music (Cleridou \& Furnham, 2014; Langmeyer et al., 2012).

The conflicting results from past studies warrant the need to identify why these differences arose. Therefore, it is the aim of this study to examine the relationship between Big Five personality traits (Openness, Conscientiousness, Extroversion, Agreeableness, and Neuroticism) and music preferences (Intense-Rebellious (IR) and Energetic-Rhythmic (ER)) among university students.

\subsection{LITERATURE REVIEW}

\section{Personality}

Personality refers to characteristic patterns of thinking, behaviours, and behaving that make up the individual differences (Kazdin, 2000). In defining personality, traits are considered as a, if not the core feature of personality by most gerontologists and psychologists belonging to different fields (Costa, McCrae, \& Löckenhoff, 2019). Thoughts, feelings, and behaviour manifest from personality traits that are believed to be almost consistent and enduring (Costa et al., 2019). The Big Five Personality Model is the most notable approach in the trait approach (Feldman, 2010). This model is also widely accepted in most taxonomies (Feldman, 2010; Larsen \& Buss, 2009). Thus, this research focuses on the Big Five Personality theory, which includes Openness, Conscientiousness, Extraversion, Agreeableness, and Neuroticism

Openness, is related to the authenticity and complexity of an individual's mental and experiential life (John \& Srivastava, 1999). Highly open individuals are very imaginative, highly sensitive to art and beauty, emotionally differentiated, and curious for intellect. In contrast, individuals who obtain a low score for this trait are less inquisitive and inflexible (McCrae \& Sutin, 2009). Next, Conscientiousness is associated with perseverance, self-discipline, and achievement-driven characteristics (Chamorro-Premuzic \& Furnham, 2005). Conscientious individuals are highly efficient, organized, determined, and productive. On the other hand, individuals who score lesser in this dimension are weak, relaxed, and collected (McCrae \& Costa Jr, 2008). Extraversion is the trait that describes individuals who show great interest in the social and external world (John \& Srivastava, 1999; Larsen \& Buss, 2009). Extraverts have a greater tendency to experience positive feelings and favour building relationships and communicating with people. In contrast, quiet, less sociable, and self-controlled individuals have low Extraversion scores (Chamorro-Premuzic \& Furnham, 2005). According to John and Srivastava (1999), Agreeableness is likened to altruism, tender-mindedness, trust, and modesty. It also shows a tendency towards positive behaviour that diverges from hostility. Individuals who possess a strong trait of Agreeableness are perceived as warm and friendly and harbouring good intentions (Ercegovac et al., 2015). Conversely, less agreeable individuals are perceived negatively as harsh and hostile (Livosky, Stevens, Hoff, \& Surawski, 2012). Neuroticism contradicts emotional stability and even-temperedness (John \& Srivastava, 1999). Thus, it is associated with negative emotions like anxiety, nervousness, sad and tension. Neurotic individuals are emotionally unstable, often filled with anxiety, stress, and fear (Friedman \& Schustack, 2009). However, less neurotic individuals are even-tempered and can cope well under pressure (Hough, Eaton, Dunnette, Kamp, \& McCloy, 1990).

\section{Music Preferences}

A way to define music preference is that it is a phenomenon that results from the interaction between an individual's personality and their complex social and cultural environment (Vuoskoski, 2017). Research on the theory of music preference by Rentfrow and Gosling (2003) reported that music preferences' development and maintenance are due to self-views, cognitive abilities, and personality. They explain that individuals listen to music that reinforces and projects their self-view, providing stimulation at the optimum level. Rentfrow and Gosling (2003) theorized that personality has an impact on individuals' music preferences.

The music preference dimensions are explained by the Short Test of Music Preferences (STOMP). According to STOMP, four music genre dimensions are known as Intense-Rebellious, Upbeat-conventional, and Energetic-Rhythmic. However, this study focuses on the dimensions of Intense-Rebellious (IR) and Energetic-Rhythmic (ER). Intense-Rebellious (IR) dimension comprises music genres full of energy and highlights rebellious themes that include rock, alternative, and heavy metal. Energetic-Rhythmic (ER) is made up of lively genres and highlights rhythms that include rap/hip-hop, soul/funk, and electronica/dance.

\section{Relationship between Personality and Music Preferences}

The link between personality and music preferences draws researchers' interest, and numerous studies have been conducted to uncover the association between the two variables. The Big Five Inventory (BFI) and STOMP are two widely used instruments in studies between personality and music preferences. The discussion on the relationships between the variables mentioned above is based on the dimensions measured by both instruments.

Firstly, Openness is found to correlate with Intense-Rebellious (IR) (Cleridou \& Furnham, 2014; Ercegovac et al., 2015; Ferwerda et al., 2017; Fricke \& Herzberg, 2017; Langmeyer et al., 2012; Rentfrow, McDonald, \& Oldmeadow, 2009; Swami et al., 2013; Tekman, 2009; ThankGod \& Lanre, 2018; Thompson et al., 2018; Vella \& Mills, 2017) and Energetic-Rhythmic (ER) (Sigg, 2009). A plausible explanation for Openness to correlate with a variety of music genres is that individuals with the trait of Openness demonstrate a preference for variety (Costa \& McCrae, 1992). For example, a study conducted by Swami et al. (2013) proposed the vocalization technique of 
screaming and unpitched vocals challenge and engaged open individuals who aid the development of preference for IR. Based on past studies, the following hypotheses are formed:

$\mathrm{H}$ 1: There is a significant relationship between Openness and IR.

$\mathrm{H}$ 2: There is a significant relationship between Openness and ER.

Similarly, studies on personality and music preferences revealed that Conscientiousness is inconsistent in predicting music preferences. Previous studies reported no significant correlation between Conscientiousness and any music preference dimensions (Brown, 2012; Dys et al., 2017; Ercegovac et al., 2015; Langmeyer et al., 2012; Livosky et al., 2012; Upadhyay, Shukla, \& Chakraborty, 2017). To explain this, McManus and Furnham (2006) demonstrated that Conscientious individuals have a narrow artistic view and less interest in visual and general art activities, inclusive of music. Thus, they do not show a preference for any music dimensions. Previous studies do not report a significant relationship between Conscientiousness and ER. On the contrary, findings from several studies reported that Conscientiousness consistently demonstrates a significant negative relationship with IR (Cleridou \& Furnham, 2014; Ferwerda et al., 2017; Fricke \& Herzberg, 2017; Greenberg et al., 2016; Herrera et al., 2018; Thompson et al., 2018). In an attempt to identify the association between personality traits and the enjoyment of death metal music, Thompson et al. (2018) stated that Conscientious individuals showed a lower preference for intense music. This might be due to conscientious individuals who cannot understand and accept the depictions of violence in IR genres. Based on past studies, the following hypotheses are formed:

H 3: There is no significant relationship between Conscientiousness and IR.

$\mathrm{H}$ 4: There is no significant relationship between Conscientiousness and ER.

Another dimension of personality, Extraversion, is found to correlate with music preferences. For instance, the mentioned personality trait are proven to predict preference for ER (Dunn et al., 2012; Ferwerda et al., 2017; Fricke \& Herzberg, 2017; Herrera et al., 2018; Langmeyer et al., 2012; Rauf \& Rasheed, 2017; Rentfrow \& Gosling, 2003; Tekman, 2009; Vella \& Mills, 2017; Zweigenhaft, 2008). To support this, Vella and Mills (2017), who conducted a study to determine whether the use of music partially mediates the link between personality and music preference, suggested that extroverts who have the tendencies to experience positive emotions prefer songs that are arousing, such as those grouped in ER. Similarly, the results between Extraversion and IR showed that extraverts prefer IR music (Langmeyer et al., 2012; Sigg, 2009; ThankGod \& Lanre, 2018). This notion is supported by one study conducted among Nigerian students who reported a high score in the Extraversion showed an increased preference for IR (ThankGod \& Lanre, 2018). They argued that extroverts preferred IR because the genres that were categorized in IR, such as alternative, heavy metal, and rock, suited the energy level of extroverts and their desire to connect with people and enjoy themselves (ThankGod \& Lanre, 2018). Based on past studies, the following hypotheses are formed:

H 5: There is a significant relationship between Extraversion and IR.

H 6: There is a significant relationship between Extraversion and ER.

Agreeableness is another personality dimension that correlates with music preferences, although the results are divergent. To further explain this, Agreeableness shows a weak correlation with ER (Fricke \& Herzberg, 2017; Livosky et al., 2012). Livosky et al. (2012) found that individuals who were nice, good-natured, and friendly preferred to listen to music with "catchy" and pleasing rhythm (ER) that resonated with their trait. Previous studies found inconsistent results between Agreeableness and IR Several studies confirmed that the more agreeable an individual is, the less likely they prefer IR music (Herrera et al., 2018; Livosky et al., 2012; Rauf \& Rasheed, 2017; Thompson et al., 2018; Upadhyay, Shukla, \& Chakraborty, 2017). Other researchers show no correlation between Agreeableness and IR (Cleridou \& Furnham, 2014; Swami et al., 2013). Thompson et al. (2018) discovered that violent music like IR might be unappealing to individuals high in Agreeableness. Based on past studies, the following hypotheses are formed:

H 7: There is a significant relationship between Agreeableness and IR.

$\mathrm{H}$ 8: There is a significant relationship between Agreeableness and ER.

Studies on the relationship between Neuroticism and music preferences yield divergent results. For instances, while there are studies that find positive and negative correlations between both dimensions, there are also studies that find no correlation between Neuroticism and any music preference dimensions (Dys et al., 2017; Livosky et al., 2012; Rentfrow \& Gosling, 2003; ThankGod \& Lanre, 2018; Upadhyay, Shukla, \& Chakraborty, 2017). A possible explanation for the lack of association between Neuroticism and music preference is that music preferences are not strongly affected by persistent emotional states (Rentfrow \& Gosling, 2003). To elaborate, while neurotic individuals were found to prefer IR (Fricke \& Herzberg, 2017; Greenberg et al., 2016; Herrera et al., 2018), some studies found neurotic individuals were less likely to prefer IR (Cleridou \& Furnham, 2014; Langmeyer et al., 2012). To exemplify, one study conducted by Herrera et al. (2018) on a large group of Brazilian found that neurotic individuals are prone to liking music associated with antisocial behaviour, such as the genres in IR. In contrast, Cleridou and Furnham (2014) found that neurotic individuals were less likely to prefer IR. As for ER's music preference dimension, no results from prior studies reported a correlation between the dimensions above and Neuroticism. Based on past studies, the following hypotheses are formed:

H 9: There is no significant relationship between Neuroticism and IR.

H 10: There is no significant relationship between Neuroticism and ER. 


\subsection{METHODOLOGY}

\section{Research Design}

A cross-sectional online survey was carried out via Facebook and WhatsApp among private and public college and university students.

Sample

The study's participants were recruited among students studying in higher education, including those studying in private and public colleges and universities. Convenience sampling and snowball sampling were employed. The survey link was promoted through Facebook and WhatsApp, inviting university and college students aged 19 and 26 to participate in the survey. Individuals who filled up the questionnaires were also asked to share and invite their friends to participate in this study. As a result, 145 (36 male, 109 female) students participated in this study. Participation in this study is voluntary.

\section{Measures}

Big 5 Personality Traits was assessed by The Big Five Inventory (BFI) developed by John and Srivastava (1999). It consists of a 44-item inventory designated to identify the five personality dimensions: Openness, Conscientiousness, Extraversion, Agreeableness, and Neuroticism. A total number of 10 out of 44 items in the inventory intends to identify Openness, 9 to identify Conscientiousness, and 8 to identify Extraversion. Another nine items are designed to identify Agreeableness, whereas the remaining eight items to identify Neuroticism. The inventory uses a 5-point Likert Scale for respondents to express their extent of agreement for each item. The scale ranging from strongly disagree to strongly agree.

The Short Test Of Music Preferences (STOMP), developed by Rentfrow and Gosling (2003), was used to measure two out of four music preferences: IR and ER. IR categorizes music genres full of energy and highlights rebellious themes, whereas ER comprises lively genres and highlights rhythm. Three items assessed preference for the IR dimension, and another three items assessed the ER dimension. STOMP uses a 7-point Likert Scale for respondents to express their agreement for each item. The scale ranges from strongly like to strongly dislike.

\section{Data Analysis}

Statistical Package for Social Science (SPSS) 21 was used to analyse the data. The demographic information consists of hours spent listening to music daily, age, gender, ethnicity, the current working or studying status, and type of university, which were tabulated in frequency, percentage, and mean. Additionally, descriptive statistics were used to identify the level of Big Five personality traits (BFI) and IR and ER music preferences among university students. Pearson correlation test was used to analyse the relationship between personality traits and music preference.

\subsection{RESULTS}

\section{Demographic Analysis}

Table 1 illustrates the demographic analysis of respondents. Almost half of the respondents spent 2 to 4 hours (40.7\%) listening to music daily. The mean age of the respondents was 22.1 ( $\mathrm{SD}=1.52)$ years old. Similarly, most of the respondents were females $(75.2 \%)$, and half were Chinese (59.3\%). The majority of the respondents were studying in public university (77\%)

Table 1 Respondents' Gender Distribution ( $\mathrm{n}=145$ respondents)

\begin{tabular}{lcc}
\hline \multicolumn{1}{c}{ Variables } & $\begin{array}{c}\text { Frequency } \\
\text { (f) }\end{array}$ & $\begin{array}{c}\text { Percentage } \\
(\boldsymbol{\%})\end{array}$ \\
\hline Hours spent listening to music per day & & \\
Less than 2 hours & 56 & 38.6 \\
2 to 4 hours & 57 & 40.7 \\
4 to 6 hours & 21 & 14.5 \\
More than 6 hours & 9 & 6.2 \\
\hline Age & & \\
22.1 (SD=1.520,19-16) & & \\
\hline Gender & 36 & 24.8 \\
Male & 109 & 75.2 \\
\hline Female & & \\
Ethnicity & 43 & 29.7 \\
Malay & 86 & 59.3 \\
Ininese & 12 & 8.3 \\
\hline
\end{tabular}




\begin{tabular}{lcc}
\hline Others & 4 & 2.8 \\
\hline Current Occupation & & \\
Student & 145 & 100 \\
\hline Place studying & 113 & 77.0 \\
Public college/university & 32 & 22.1 \\
Private college/university & 145 & 100 \\
\hline Total $\quad \mathrm{SD}=$ Standard deviation & &
\end{tabular}

Big Five Personality Traits

Table 2 shows the overall mean score of the Big Five personality traits of respondents. The findings show that all the Big Five personality traits were at a moderate level. Among the five traits, Agreeableness had the highest overall mean score, and it is followed by Openness $(\mu=3.55, \mathrm{SD}=0.513)$, Conscientiousness $(\mu=3.24, \mathrm{SD}=0.534)$, and Neuroticism $(\mu=3.09, \mathrm{SD}=0.713)$. The trait with the lowest overall mean score was Extraversion $(\mu=2.94, \mathrm{SD}=0.704)$.

Table 2 Level of Big Five Traits

\begin{tabular}{ll}
\hline Dimensions & Mean $($ SD. $)$ \\
\hline Openness & $3.55(0.513)$ \\
Conscientiousness & $3.24(0.534)$ \\
Extraversion & $2.94(0.704)$ \\
Agreeableness & $3.66(0.501)$ \\
Neuroticism & $3.09(0.713)$ \\
\hline \multicolumn{2}{c}{ SD=Standard deviation }
\end{tabular}

\section{Music Preferences}

Table 3 demonstrates the overall mean score for music preference dimensions. Based on the table, ER $(\mu=4.38, \mathrm{SD}=1.264)$ had a high overall mean score, whereas IR had a low overall mean score $(\mu=3.55, \mathrm{SD}=1.240)$. Respondents preferred ER music more than IR.

Table 3 Level of Music Preferences

\begin{tabular}{ll}
\hline Dimensions & Mean (SD.) \\
\hline IR & $3.55(1.240)$ \\
ER & $4.38(1.264)$ \\
\hline \multicolumn{2}{c}{ SD=Standard deviation }
\end{tabular}

Relationship between Big Five Personality and Music Preferences among University Students in Malaysia

Table 3 presents the results of the relationship between Bif Five Personality traits and music preferences. Referring to the table, Openness was the only personality trait that significantly correlates with ER. This leads to the acceptance of Hypothesis 2 . The more Open an individual is, the more likely they prefer music that is energetic and rhythmic.

According to Table 3, other personality traits such as Conscientiousness, Extraversion, Agreeableness, and Neuroticism do not significantly correlate with any music preference dimensions. Hypotheses 1, 3,4,5,6,7,8,9 and 10 were rejected.

Table 3 Correlations between the BFI and STOMP

\begin{tabular}{ccccc}
\hline & & IR & & \multicolumn{2}{c}{ ER. } \\
\hline & $r$ & $p$ & $r$ & $p$ \\
\hline Openness & 0.030 & 0.718 & $0.252^{*}$ & 0.002 \\
Conscientiousness & 0.010 & 0.904 & 0.089 & 0.288 \\
Extraversion & -0.067 & 0.422 & 0.135 & 0.106 \\
Agreeableness & -0.018 & 0.831 & 0.101 & 0.277 \\
Neuroticism & 0.002 & 0.984 & 0.005 & 0.953 \\
\hline
\end{tabular}

\subsection{DISCUSSION AND RECOMMENDATION}

\section{Discussion on Big Five Personality Traits and Music Preferences}

This study revealed that the most prevalent traits among respondents were Agreeableness, Openness, and Conscientiousness. The findings are consistent with studies conducted by Ercegovac et al. (2015), Livosky et al. (2012), ThankGod and Lanre (2018), and Yoo et al. (2018). On the other hand, Neuroticism and Extraversion were less prevalent compared to the other three traits. Similarly, these findings are in line with the past studies (Ercegovac et al., 2015; Livosky et al., 2012; ThankGod \& Lanre, 2018; Yoo et al., 2018). In one study by 
Andi (2012), Agreeableness, Openness, and Conscientiousness were three traits that showed a positive trend from teenagers (15 to 16 years old) to middle age youth ( 25 to 29 years old). As the overall scores of Agreeableness, Conscientiousness, and Openness showed a positive trend among youth in Malaysia, this positive trend could explain why these traits had higher overall mean scores in this study. This study found Neuroticism and Extraversion to be less prevalent; they had lower overall scores than other traits. It can be concluded that students in tertiary education are friendly (Ercegovac et al., 2015), curious for intellect (McCrae \& Sutin, 2009), highly efficient and productive (Chamorro-Premuzic \& Furnham, 2005), and emotionally stable (Fricke \& Herzberg, 2017). They are also quiet and have greater selfcontrol (Chamorro-Premuzic \& Furnham, 2005).

This study reports that university students preferred listening to ER to IR music. These results are in line with prior work done by Cleridou and Furnham (2014), Song et al. (2018), and ThankGod and Lanre (2018). Similarly, past studies also show that IR was less preferred than ER (Brown, 2012; Cleridou \& Furnham, 2014; Sigg, 2009; ThankGod \& Lanre, 2018). Referring to the study by Bonneville-Roussy et al. (2013), preference for ER increased during adolescence then stabilized during young adulthood, while the choice for IR fell sharply during adolescence before a remained plateau in young adulthood. The rise and fall of ER and IR preference explain why one music preference dimension is more preferable than the other in this study.

Additionally, IR is less preferred because it is difficult to access music in the IR dimension, such as heavy metal. Historically, heavy metal and its subgenres were pushed underground due to moral panic of national proportions, creating a fear that society's well-being was being threatened by some evil, from 2001 to 2006 in Malaysia (Ferrarese, 2014). The rise of urban music includes genres like hip-hop and rap becoming popular since 2000 (Khattriza Ahmad Saffian, Khairunnisa Diyana Mod Noor, \& Yeoh, 2016). Since then, such music has been promoted until today through record labels, local radio and television stations, and avenues for music performance, which are also promoting the new theme (Khattriza Ahmad Saffian et al., 2016).

Discussion on Relationship Between Big Five Personality and Music Preferences among College and University Students in Malaysia

In determining the relationship between personality and music preferences, only Openness correlates significantly albeit weakly with ER, whereas other traits do not correlate with any music preference dimensions. This finding is in line with Sigg (2009), while other studies did not reveal a significant relationship between Openness and ER. Thus, more studies are necessary to understand this relationship.

Surprisingly, unlike past studies (Cleridou \& Furnham, 2014; Ercegovac et al., 2015; Ferwerda et al., 2017; Fricke \& Herzberg, 2017; Langmeyer et al., 2012; Rentfrow et al., 2009; Swami et al., 2013; Tekman, 2009; ThankGod \& Lanre, 2018; Thompson et al., 2018; Vella \& Mills, 2017), Openness does not predict the preference of IR. Prior work has consistently reported individuals scoring high in the Open dimension to prefer IR as such music is dynamic and exciting and can evoke curiosity (Vella \& Mills, 2017). On top of that, they show preference and are appreciative of IR as music in this dimension is outside of the mainstream palette (Vella \& Mills, 2017) and its depth and structure (ThankGod \& Lanre, 2018). The findings where Openness correlates with ER instead of IR are very similar to the results by Sigg (2009). The author also found Openness to associate with ER instead of IR postulated that the contradicting findings could be attributed to cultural differences. Apart from Openness, Extraversion, Conscientiousness, Agreeableness, and Neuroticism, it did not show a significant preference for any music dimension.

In the current study, Conscientiousness is revealed to show no significant correlation with any music preference dimension. This aligns with past studies (Brown, 2012; Dys et al., 2017; Ercegovac et al., 2015; Livosky et al., 2012). This study fails to replicate past studies' findings where Conscientiousness predicted preference for IR (Cleridou \& Furnham, 2014; Fricke \& Herzberg, 2017; Greenberg et al., 2016; Thompson et al., 2018). Herrera et al. (2018) reported a negative correlation between Conscientiousness and IR, stated that this was due to the specific aspects of their personality, such as responsibility and discipline. However, this study confirms the hypothesis that Conscientiousness does not correlate with ER. Prior work rarely discusses the correlation between Conscientiousness and ER as they did not find a meaningful correlation. To further explain this, the connection between Conscientiousness and conservatism might account for the lack of a significant relationship between Conscientiousness and music preferences. Conscientious individuals have a narrow artistic view and are less interested in visual art and general art activities (McManus \& Furnham, 2006). On top of that, the nature of Conscientiousness that contradicts artistic, intuitive and imagination (Costa \& McCrae, 1992; Eysenck, 1992, 1993; Matthews \& Deary, 1998) to some extent might lead Conscientious individuals to experience music in rational ways (Chamorro-Premuzic \& Furnham, 2007). Therefore, they do not show significant music preference.

Contrary to expectations, the results for Extraversion are not supported by past studies. The current study found no significant correlation between the said trait and any music preference dimensions. However, previous studies found that Extroverts showed a significant preference for IR (Langmeyer et al., 2012; Sigg, 2009; ThankGod \& Lanre, 2018) and ER (Dunn et al., 2012; Ferwerda et al., 2017; Fricke \& Herzberg, 2017; Langmeyer et al., 2012; Rauf \& Rasheed, 2017; Rentfrow \& Gosling, 2003; Tekman, 2009; Vella \& Mills, 2017; Zweigenhaft, 2008). In ThankGod and Lanre's (2018) study, they argued that Extroverts preferred IR because genres associated with IR suit their energy level and desire to connect with people and enjoy themselves. Extroverts full of energy, conversational, and forgiving by nature (Rentfrow \& Gosling, 2003) frequent places that play energetic and rhythmic songs such as parties and social gatherings (ThankGod \& Lanre, 2018). Thus, developing preferences for the music preference dimension of ER. More researches are needed despite this evidence as there is no clear understanding of the relationship between Extraversion and IR and ER.

Similar to Extraversion, Agreeableness also does not show a correlation with any music preference dimensions. This contradicts work done previously as studies in the past show Agreeableness correlate negatively with IR (Livosky et al., 2012; Rauf \& Rasheed, 2017; Thompson et al., 2018; Upadhyay, Shukla, \& Chakraborty, 2017) and positively with ER (Ferwerda et al., 2017; Livosky et al., 2012). In a study done by Thompson et al. (2018), the authors state that violent music such as those in IR might be unappealing to highly Agreeable individuals. Thus, they did not enjoy such genres. Livosky et al. (2012) found that individuals who were nice, good-natured, and friendly preferred music with a "catchy" and pleasing rhythm that resonated with their trait.

Contrary to past studies, this study does not obtain statistical evidence that the more Neurotic an individual is, the more they prefer IR (Ferwerda et al., 2017; Fricke \& Herzberg, 2017; Greenberg et al., 2016; Herrera et al., 2018; Langmeyer et al., 2012). For instance, Herrera et al. (2018) revealed that emotional stability, the opposite end of neuroticism, is negatively correlated with IR. They remarked that highly neurotic individuals indeed prefer music that identifies with antisocial behaviour. Greenberg et al. (2016), whose research results 
agree with Herrera et al. (2018), added that Neuroticism was positively associated with highly arousing music, and music in IR is highly arousing. One study which failed to find a significant correlation between Neuroticism and IR (Livosky et al., 2012) noted that it was puzzling as to why Neuroticism would predict preference in children but not in those studying in colleges. Despite no significant correlation between Neuroticism and ER, this is supported by numerous previous work (Dys et al., 2017; Livosky et al., 2012; Rentfrow \& Gosling, 2003; ThankGod \& Lanre, 2018; Upadhyay, Shukla, \& Chakraborty, 2017). The lack of association may be because music preferences are not strongly affected by persistent emotional states as song choices that reflect these states by individuals are affected by the mood the individual is in (Rentfrow \& Gosling, 2003). The mood could be affected by emotional conditions (Rentfrow \& Gosling, 2003). To support this, the results from a study conducted by Ferwerda, Tkalcic, Yang, and Schedl (2015) also showed that apart from genre taxonomy, high Neuroticism also predicted activity taxonomy preference. However, Rentfrow and Gosling (2003) maintained that personality still correlate with individuals' generally preferred music preference dimensions

\section{Limitations and Recommendation}

Despite providing meaningful insights into the relationship between personality and music preferences, this study possesses several limitations. Firstly, this study sample is small and does not represent Malaysia's actual demographic composition, limiting how findings can be generalized across university students. The use of the probability sampling technique could improve the study's generalization. The current research involves a relatively high degree of familiarity with different genres, and it is possible that respondents incorrectly classify song genres, which leads to data inaccuracy. Hence, to reduce this, future researchers can play excerpts that best reflect each genre for subjects to rate the extent to which they like or dislike each genre.

Next, this study examined only the relationship between personality and two music preference dimensions. Another two music preference dimensions, RC and UC, are excluded. This limits the results that can be drawn on the relationship between personality and different music preference dimensions. Thus, future studies are encouraged to include all music preference dimensions.

\subsection{CONCLUSION}

This study identifies Agreeableness, Conscientiousness, and Openness as the most prevalent traits among students in Malaysian colleges and universities. Students prefer to listen to ER music than IR. Openness was the only trait that correlates with ER. The finding contradicted past studies, whereby almost all past studies showed that individuals high in the Open dimension had a high preference for IR. On the ground that there are inconsistencies between the current research and previous studies, more investigations are needed to uncover the link between personality and music preferences.

\section{References}

Andi, H. K. (2012). Personality attributes of Malaysian youth: Age differences in Big Five domains From 15 to 39 . International Journal of Asian Social Science, 2(11), 1998-2008

Ang, M., \& Yeoh, M. (2002). Music preferences of Malaysian students and KBSM curriculum implications. 10(1), 43-51.

Bonneville-Roussy, A., Rentfrow, P. J., Xu, M. K., \& Potter, J. (2013). Music through the ages: trends in musical engagement and preferences from adolescence through middle adulthood. Journal of Personality and Social Psychology, 105(4), 703-717. doi: 10.1037/a0033770

Brown, R. A. (2012). Music preferences and personality among Japanese university students. International Journal of Psychology, 47(4), 259-268. doi: $10.1080 / 00207594.2011 .631544$

Cambridge Dictionary Online. (2019). from https://dictionary.cambridge.org/dictionary/english/higher-education

Chamorro-Premuzic, T., \& Furnham, A. (2005). Personality and intellectual competence. Mahwah, NJ, US: Lawrence Erlbaum Associates Publishers.

Chamorro-Premuzic, T., \& Furnham, A. (2007). Personality and music: Can traits explain how people use music in everyday life? British Journal of Psychology, 98(2), 175-185. doi: 10.1348/000712606x111177

Cleridou, K., \& Furnham, A. (2014). Personality correlates of aesthetic preferences for art, architecture, and music. Empirical Studies of the Arts, 32(2), 231-255. doi: 10.2190/EM.32.2.f

Costa, P. T., \& McCrae, R. R. (1992). Revised Neo Personality Inventory (NEO PI-R) and Neo Five-Factor Inventory (Neo-FFI) : Professional Manual. Odessa (FL) PAR.

Costa, P. T., McCrae, R. R., \& Löckenhoff, C. E. (2019). Personality across the life span. Annual Review of Psychology, 70(1), 423-448. doi: 10.1146/annurev-psych010418-103244

Devenport, S. P., \& North, A. C. (2019). Predicting musical taste: Relationships with personality aspects and political orientation. Psychology of Music, 47(6), 834847. doi: $10.1177 / 0305735619864647$

DeYoung, C. G., Quilty, L. C., \& Peterson, J. B. (2007). Between facets and domains: 10 aspects of the Big Five. Journal of Personality and Social Psychology, 93(5), 880-896. doi: 10.1037/0022-3514.93.5.880

Dunn, P. G., de Ruyter, B., \& Bouwhuis, D. G. (2012). Toward a better understanding of the relation between music preference, listening behavior, and personality. Psychology of Music, 40(4), 411-428. doi: 10.1177/0305735610388897

Dys, S. P., Schellenberg, E. G., \& McLean, K. C. (2017). Musical identities, music preferences, and individual differences Handbook of Musical Identities. Oxford: Oxford University Press.

Ercegovac, I. R., Dobrota, S., \& Kuscevic, D. (2015). Relationship between music and visual art preferences and some personality traits. Empirical Studies of the Arts, 33(2), 207-227. doi: 10.1177/0276237415597390

Eysenck, H. J. (1992). Four ways five factors are not basic. Personality and Individual Differences, 13(6), 667-673.

Eysenck, H. J. (1993). Creativity and personality: Suggestions for a theory. Psychological inquiry, 4(3), $147-178$.

Feldman, R. S. (2010). Essesntials of understanding psychology: McGraw-Hill Education.

Ferrarese, M. (2014). Kami semua headbangers: Heavy metal as multiethnic community builder in Penang Island, Malaysia. International Journal of Community Music, 7. doi: 10.1386/ijcm.7.2.153_1

Ferwerda, B., Tkalcic, M., \& Schedl, M. (2017). Personality traits and music genres: What do people prefer to listen to? Paper presented at the Proceedings of the 25th Conference on User Modeling, Adaptation and Personalization, Bratislava, Slovakia.

Ferwerda, B., Tkalcic, M., Yang, E., \& Schedl, M. (2015). Personality traits predict music taxonomy preferences. Paper presented at the Proceedings of the 33rd Annual ACM Conference Extended Abstracts on Human Factors in Computing Systems, Seoul, Republic of Korea. 
Fricke, K. R., \& Herzberg, P. Y. (2017). Personality and self-reported preference for music genres and attributes in a German-speaking sample. Journal of Research in Personality, 68, 114-123. doi: 10.1016/j.jrp.2017.01.001

Friedman, H. S., \& Schustack, M. W. (2009). Personality: Classic theories and modern research: Pearson Allyn \& Bacon.

Gowensmith, W. N., \& Bloom, L. J. (1997). The effects of heavy metal music on arousal and anger. Journal of Music Therapy, 34(1), 33-45. doi: 10.1093/jmt/34.1.33

Greenberg, D. M., Kosinski, M., Stillwell, D. J., Monteiro, B. L., Levitin, D. J., \& Rentfrow, P. J. (2016). The song is you: Preferences for musical attribute dimensions reflect personality. Social Psychological and Personality Science, 7(6), 597-605. doi: 10.1177/1948550616641473

Herrera, L., Soares-Quadros, J. F., \& Lorenzo, O. (2018). Music preferences and personality in Brazilians. Frontiers in Psychology, 9. doi: 10.3389/fpsyg.2018.01488

Hough, L. M., Eaton, N. K., Dunnette, M. D., Kamp, J. D., \& McCloy, R. A. (1990). Criterion-related validities of personality constructs and the effect of response distortion on those validities. Journal of Applied Psychology, 75(5), 581-595. doi: 10.1037/0021-9010.75.5.581

John, O. P., \& Srivastava, S. (1999). The Big Five Trait taxonomy: History, measurement, and theoretical perspectives Handbook of personality: Theory and research, 2nd ed. (pp. 102-138). New York, NY, US: Guilford Press.

Kazdin, A. E. (2000). Encyclopedia of psychology. Washington, DC; Oxford [Oxfordshire]; New York: American Psychological Association ; Oxford University Press.

Khattriza Ahmad Saffian, Khairunnisa Diyana Mod Noor, \& Yeoh, P. A. (2016). "What's up indie? The Malaysia context". Paper presented at the 2nd International Music and Performing Arts Conference (IMPAC2016) Faculty of Music and Performing Arts, Universiti Pendidikan Sultan Idris UPSI, Tanjung Malim Perak, Malaysia.

Kumar, R. (2010). Research methodology: A step-by-step guide for beginners: SAGE Publications.

Langmeyer, A., Guglhor-Rudan, A., \& Tarnai, C. (2012). What do music preferences reveal about personality? A cross-cultural replication using self-ratings and ratings of music samples. Journal of Individual Differences, 33(2), 119-130. doi: 10.1027/1614-0001/a000082

Larsen, R. J., \& Buss, D. M. (2009). Personality psychology: Domains of knowledge about human nature: McGraw-Hill Education.

Livosky, M., Stevens, L. B., Hoff, R., \& Surawski, M. (2012). Personality and music preferences in college students and young children. Psychology Journal, 9(1), 1325 .

Matthews, G., \& Deary, I. J. (1998). Personality traits. New York, NY, US: Cambridge University Press.

McCrae, R. R., \& Costa Jr, P. T. (2008). Empirical and theoretical status of the five-factor model of personality traits. In G. J. Boyle, G. Matthews \& D. H. Saklofske (Eds.), The SAGE handbook of personality theory and assessment, Vol 1: Personality theories and models, 273-294. Thousand Oaks, CA, US: Sage Publications, Inc.

McCrae, R. R., \& Sutin, A. R. (2009). Openness to experience. In M. R. Leary \& R. H. Hoyle (Eds.), Handbook of individual differences in social behavior. (pp. 257273). New York, NY, US: The Guilford Press.

McManus, I. C., \& Furnham, A. (2006). Aesthetic activities and aesthetic attitudes: influences of education, background and personality on interest and involvement in the arts. Br J Psychol, 97(Pt 4), 555-587. doi: 10.1348/000712606x101088

McNamara, L., \& Ballard, M. E. (1999). Resting arousal, sensation seeking, and music preference. Genetic, Social, and General Psychology Monographs, 125(3), 229-250.

Pilgrim, L., Norris, J. I., \& Hackathorn, J. (2017). Music is awesome: Influences of emotion, personality, and preference on experienced awe. Journal of Consumer Behaviour, 16(5), 442-451. doi: 10.1002/cb.1645

Rauf, K., \& Rasheed, S. (2017). The relation of music preference and personality type. Pakistan Business Review, 19(3), 13. doi: 10.22555/pbr.v19i3.1642

Rentfrow, P. J., \& Gosling, S. D. (2003). The do re mi's of everyday life: The structure and personality correlates of music preferences. Journal of Personality and Social Psychology, 84(6), 1236-1256. doi: 10.1037/0022-3514.84.6.1236

Rentfrow, P. J., McDonald, J. A., \& Oldmeadow, J. A. (2009). You are what you listen to: Young people's stereotypes about music fans. Group Processes \& Intergroup Relations, 12(3), 329-344. doi: 10.1177/1368430209102845

Schäfer, T. (2016). The goals and effects of music listening and their relationship to the strength of music preference. PLOS ONE, 11(3), e0151634. doi: 10.1371/journal.pone.0151634

Schäfer, T., \& Sedlmeier, P. (2010). What makes us like music? Determinants of music preference. Psychology of Aesthetics, Creativity, and the Arts, 4(4), 223-234. doi: $10.1037 / \mathrm{a} 0018374$

Sigg, N. (2009). An Investigation Into The Relationship Between Music Preference, Personality And Psychological Well-Being. (Master of Health Science (psychology) Masters), Aukland University of Technology.

Song, B. W. L., Selvan, M. T., Menon, S. J. P., Lee, W. K., \& Jamalludin, Z. (2018). Association of gender, ethnicity, personality, leadership skills and Its influence on music preferences among medical students in Malaysia. American Journal of Social Science Research, 4(3), 60-68.

Swami, V., Malpass, F., Havard, D., Benford, K., Costescu, A., Sofitiki, A., \& Taylor, D. (2013). Metalheads: The influence of personality and individual differences on preference for heavy metal. Psychology of Aesthetics Creativity and the Arts, 7(4), 377-383. doi: 10.1037/a0034493

Tekman, H. G. (2009). Music preferences as signs of who we are: Personality and social factors. Paper presented at the Proceedings of the 7th Triennial Conference of European Society for the Cognitive Sciences of Music, Jyväskylä, Finland

ThankGod, U., Ocheho, \& Lanre, F., Babalola. (2018). The relationship between personality traits and preference for music genres among students of Redeemer's University, Ede. Research on Humanities and Social Sciences, 8(10), 110-116.

Thompson, W. F., Geeves, A. M., \& Olsen, K. N. (2018). Who enjoys listening to violent music and why? Psychology of Popular Media Culture. doi: $10.1037 / \mathrm{ppm} 0000184$

Upadhyay, D. K., Shukla, R., \& Chakraborty, A. (2017). Factor structure of music preference scale and its relation to personality. Journal of the Indian Academy of Applied Psychology, 43(1), 104-113.

Upadhyay, D. K., Shukla, R., Tripathi, V. N., \& Agrawal, M. (2017). Exploring the nature of music engagement and its relation to personality among young adults. International Journal of Adolescence and Youth, 22(4), 484-496. doi: 10.1080/02673843.2016.1245150

Vella, E. J., \& Mills, G. (2017). Personality, uses of music, and music preference: The influence of Openness to experience and extraversion. Psychology of Music, 45(3), 338-354. doi: 10.1177/0305735616658957

Vuoskoski, J. K. (2017). Musical preference, personality, style, and music use.

Vuoskoski, J. K., Thompson, W. F., McIlwain, D., \& Eerola, T. (2012). Who enjoys listening to sad music and why? Music Perception, 29(3), 311-317. doi: $10.1525 / \mathrm{mp} .2012 .29 .3 .311$

Yeoh, M. (2014). Music preferences of teenage students in relation to listener psychology. (Doctor of Philosphy), University Putra Malaysia.

Yeoh, M., Mahyuddin, R., K Ang, M., \& Konting, M. (2001). Music preferences of Malaysian students and national integration.

Yoo, H., Kang, S., \& Fungi, V. (2018). Personality and world music preference of undergraduate non-music majors in South Korea and the United States. Psychology of Music, 46(5), 611-625. doi: 10.1177/0305735617716757

Zweigenhaft, R. L. (2008). A do re mi encore: A closer look at the personality correlates of music preferences. Journal of Individual Differences, 29(1), 45-55. doi: $10.1027 / 1614-0001.29 .1 .45$ 